\title{
Preharvest Fruit Drop in Huanglongbing-affected 'Valencia' Sweet Orange
}

\author{
Lisa Tang, Shweta Chhajed, and Tripti Vashisth ${ }^{1}$ \\ Citrus Research and Education Center, University of Florida/IFAS, 700 Experiment Station Road, \\ Lake Alfred, FL 33850
}

Additional Index words. Candidatus Liberibacter asiaticus, Citrus sinensis, fruit detachment force, fruit abscission, CEL6, PG20, PL5, EXP10

\begin{abstract}
For field-grown 'Valencia' sweet orange (Citrus sinensis) affected by Huanglongbing [HLB (Candidatus Liberibacter asiaticus (CLas)], trees that displayed more severe HLB symptoms (severe trees) had $74 \%$ fruit drop before harvest; however, the drop rate for less symptomatic trees (mild trees) was $45 \%$. For mature fruit (3 weeks before harvest) still attached to the branches, $60 \%$ of them from severe trees were "loose fruit" [fruit detachment force (FT) < $6 \mathrm{kgf}$. In contrast, only $13 \%$ of the attached fruit from the mild trees were loose. Overall, fresh weight and size of loose fruit were lower than "tight fruit" (FT > $6 \mathrm{kgf}$ ). Irrespective of the symptom levels of trees, the concentrations of glucose, fructose, and inositol in juice of loose fruit were the same or larger than those of tight fruit, suggesting that the shortage of carbohydrates is not the dominant cause of HLB-associated preharvest fruit drop. Expression levels of the cell wall modification genes encoding cellulase (endo-1,4- $\beta$-glucanase), polygalacturonase, and pectate lyase were greater in the calyx abscission zones of loose fruit compared to tight fruit, indicating that cell separation was occurring in the former at the time of collection. No differences in the expression levels of genes encoding the ethylene biosynthesis enzymes, including 1-aminocyclopropane-1-carboxylic acid (ACC) synthase (ACS) and $A C C$ oxidase $(A C O)$, and an ethylene-responsive transcription factor 1 (ERF1) were observed in tissues of loose and tight fruit. Interestingly, $A C S, A C O$, and $E F R 1$ expressions were lower in calyx abscission zones and in leaves of the severe trees compared with those of mild trees, suggesting an ostensible, HLB-dependent reduction in ethylene biosynthesis and/or signaling close to harvest time. However, the role of ethylene in HLB-associated preharvest fruit drop remains to be determined. The results leave open the possibility of early ethylene production and action before the initiation of fruit abscission.
\end{abstract}

Since its discovery in Florida in 2005, HLB, or citrus greening, has become one of the most devastating diseases of citrus (Citrus sp.) because it causes the decline of trees within only a few years after infection, thereby leading to substantial economic loss for the citrus industry (Alvarez et al., 2016; Halbert, 2005). In Florida, the most prevalent cause of HLB in Florida is CLas, which is a phloem-limited bacterium that is transmitted by asian citrus psyllid (Diaphorina citri) (Halbert et al., 2000; Jagoueix et al., 1994). There is no cure for HLB, and its symptoms include blotchy mottled leaves, branch dieback, and small lopsided fruit with aborted seeds (Bové, 2006). In addition, HLB causes an increase in preharvest fruit drop, which is defined as the abscission of mature fruit (during stage III of fruit development) that takes place at the calyx (between the peduncle and fruit) up to 3 months before the commercial harvest (Bové, 2006; Ferguson and GraftonCardwell, 2014; Iglesias et al., 2007). Increased preharvest fruit drop together with tree decline due to CLas infection results in a great reduction in yield and difficulty in field management of HLB-affected groves (Albrigo and Stover, 2015; Bové, 2006). A report released by the U.S. Department of Agriculture (USDA, 2018) indicated a dramatic increase in the estimated preharvest drop rate for 'Valencia' sweet orange from $14 \%$ during the $2009-10$ production season to $30 \%$ during the 2016-17 season; therefore, HLB is becoming epidemic throughout Florida.

Received for publication 19 Dec. 2018. Accepted for publication 29 Jan. 2019. We thank Tony Trama and Taylor S. Livingston for their technical support with carbohydrate analysis and field-related activities.

${ }^{1}$ Corresponding author. E-mail: tvashisth@ufl.edu.
To date, how HLB escalates preharvest drop in citrus remains unclear. The plugging of sieve pores and phloem collapse have been documented in leaves of HLB-affected sweet orange (Etxeberria et al., 2009; Kim et al., 2008). Sucrose, the major photoassimilate transported in the phloem, has been shown to accumulate in symptomatic leaves of HLBaffected trees compared with healthy trees, suggesting that sugar transport in the phloem is blocked (completely or partially) in the presence of CLas infection (Kim et al., 2008). In 'Valencia' sweet orange, the sucrose content in the peels of mature fruit from trees exhibiting HLB symptoms was lower than that of mature fruit collected from healthy trees (Rosales and Burns, 2011). Recently, studies involving global transcriptomic analyses have provided evidence suggesting that, in addition to phloem blockage, alterations in the carbohydrate concentrations in fruit of HLB-affected trees are attributed to disrupted carbohydrate metabolism and transport at the cellular level (Liao and Burns, 2012; Martinelli et al., 2012). It is of interest that a shortage in carbohydrates is the predominant cause of citrus fruitlet drop $\approx 1$ to 2 months following anthesis, which is also known as June drop (Goldschmidt, 1999; Goldschmidt and Koch, 1996; Goldschmidt and Monselise, 1977; Gómez-Cadenas et al., 2000; Ruiz et al., 2001). Taken together, these results have led to the possibility that blockage of the carbohydrate flow in the phloem due to HLB might result in limited carbohydrate availability to the fruit, thereby leading to increased preharvest fruit drop; this process is similar to that causing fruitlet abscission during June drop.

Abscission is the physiological process of plant organ (such as fruit, flowers, leaves) separation from the whole plant body. 
Abscission occurs at the abscission zone (AZ), a specific region of cells that is developmentally programmed during the cell differentiation stage; however, the process of abscission is not initiated until the signal transduction pathway is activated (Kim, 2014; Patharkar and Walker, 2018; Patterson, 2001). The endogenous plant hormone ethylene is one of the key players that signals and triggers the up-regulation of cell wall hydrolytic enzymes, such as endo-1,4-glucanase (cellulase), polygalacturonase (PG), pectate lyase (PL), and pectin methylesterase (PME), resulting in dissolution of the middle lamella that connects the two adjacent cells and leading to cell separation (González-Carranza et al., 2002, 2007; Kim, 2014; Patterson, 2001). In addition, in Arabidopsis (Arabidopsis thaliana), the expression of expansin10 (EXP10), a member of the expansin (EXP) transcription family, at the base of the pedicel where abscission occurs suggests that this gene has a role in the regulation of cell wall modification during the abscission process (Cho and Cosgrove, 2000). For healthy 'Valencia' sweet orange and 'Washington' navel orange (C. sinensis), exogenously applied ethylene and its precursor ACC induced abscission of mature fruit (Malladi and Burns, 2008; Merelo et al., 2017; Yuan et al., 2005). In addition, at the calyx AZ (AZ-C), where mature fruit abscission occurs, $E R F 1$, the gene encoding an ethylene-responsive factor that acts as a transcription factor at the downstream of ethylene signaling pathway, was up-regulated at 4 and $24 \mathrm{~h}$ after the ethylene treatment, followed by up-regulation of the cell wall hydrolytic genes at $24 \mathrm{~h}$ after treatment compared with the untreated control in healthy 'Olinda' sweet orange (Cheng et al., 2015), suggesting the involvement of ethylene in the regulation of fruit abscission in citrus. Nevertheless, the role of ethylene in HLB-associated preharvest fruit drop remains to be determined.

Currently, the use of plant growth regulators is not able to consistently or effectively control the increased rate of preharvest fruit drop in HLB-affected trees (Albrigo and Stover, 2015). To develop a strategy to mitigate this problem, it is necessary to understand the underlying mechanism of mature fruit abscission due to HLB. Therefore, the goal of this research was to gain insight into HLB-associated preharvest fruit drop. This study compared the cumulative preharvest fruit drop rate of mature fruit from January through May of 'Valencia' sweet orange trees exhibiting mild, moderate, and severe levels of HLB symptoms. To determine the inherent differences between fruit that were inclined to remain on trees (tight fruit) and those with a high tendency to abscise (loose fruit), this study compared the fruit characteristics and quality between these two types of 'Valencia' sweet orange fruit from trees with the three aforementioned HLB symptom levels. Therefore, there were six combinations of fruit types (tight or loose fruit) and symptom levels (mild, moderate, or severe). The carbohydrate levels in juice and source leaves as well as the expression of genes for carbohydrate metabolism and transport were analyzed to determine whether mature fruit abscission is related to carbohydrate shortage in HLB-affected trees. Finally, we assessed the connection between endogenous ethylene and HLB-associated preharvest fruit drop. The expression of the genes for ethylene biosynthesis and response and those related to abscission, including cell wall modification and cell expansion, were analyzed in AZ-C, peels, and leaves of the six combinations of fruit types and symptom levels.

\section{Materials and Methods}

Plant materials. Fifteen-year-old 'Valencia' sweet orange trees on 'Swingle' citrumelo (Citrus paradisi $\times$ Poncirus trifoliata) rootstock in an experimental orchard at the University of Florida Citrus Research and Education Center in Lake Alfred were used for this research. Currently, because of the prevalence of HLB in Florida, it is unlikely to find healthy CLas-negative sweet orange trees as controls in openair groves. Therefore, trees $(n=4)$ exhibiting mild, moderate, and severe visual symptoms of HLB based on the rating system developed by the Citrus Research and Development Foundation in Lake Alfred, FL (as described by Slinski, 2016) were selected to investigate the effects of HLB severity on preharvest fruit drop in this study.

EVALUATION OF PREHARVEST FRUIT DROP AND DIFFERENTIATION OF TWO TYPES OF FRUIT. The number of dropped fruit on the ground from all trees was recorded every $\approx 2$ to $7 \mathrm{~d}$ from 27 Jan. through 25 May 2017, and $1 \mathrm{~d}$ before harvest. The number of fruit remaining on trees was counted during harvest on 26 May 2017 to calculate the cumulative drop rate.

For each tree, 10 fruit that were still attached to the tree branches were collected by clipping the branches with leaves $\approx 20 \mathrm{~cm}$ long from the calyx; these were taken to the laboratory during 1 May through 4 May $2017(\approx 3$ weeks before harvest; one replicate of all symptom levels was processed each day). Only the branches bearing single fruit at the distal position were collected. These attached fruit were further separated into tight fruit and loose fruit based on the value of the FT, which determines how much force is required for the fruit to be "pulled" or detached from the tree/branch, that was measured using a digital force gauge (Force One; Wagner Instruments, Greenwich, CT). Whereas tight fruit, for which FT was $>6$ kgf (Malladi and Burns, 2008), were not physiologically ready to abscise, loose fruit with FT $\leq 6 \mathrm{kgf}$ represented fruit with a high tendency to drop at the time of collection.

Physical ANd Chemical Characteristics of leaves AND FRUIT. The dark green and leathery mature (source) leaves, including healthy and HLB symptomatic (botchy mottled) leaves, on 20-cm-long branches were excised and counted. The area of the source leaves for individual fruit was quantified by measuring the scanned leaves using ImageJ software (Easlon and Bloom, 2014; Schneider et al., 2012).

The fresh weight of each fruit was recorded, along with the transverse diameter, which was measured with an electronic caliper. The AZ-C and peel (albedo and flavedo) were excised, followed by juice extraction by hand. For each fruit type combination (tight or loose fruit) and symptom level of the tree (mild, moderate, or severe tree), the AZ-C, peel, and leaf tissues were pooled after excision, immediately frozen in liquid nitrogen, and stored at $-80{ }^{\circ} \mathrm{C}$ until further use; juice was combined and stored at $-20{ }^{\circ} \mathrm{C}$. The contents of total soluble solids (TSS) and titratable acidity (TA) in juice were determined using a handheld refractometer (Pocket PAL-BX1 ACID1; Atago USA, Bellevue, WA). The maturity index is expressed as the ratio of TSS to TA. Healthy and aborted seeds (Rosales and Burns, 2011) and total seeds (the sum of healthy and aborted seeds) of each fruit were also quantified.

ANALYSIS OF CARBOHYDRATES IN LEAVES AND JUICE. The levels of sucrose, fructose, glucose, and inositol were quantified in leaves and juice using ion chromatography (IC). For extraction 
and quantification, the protocol by Cataldi et al. (2000) was used, with some modifications. Briefly, $1 \mathrm{~g}$ of ground leaf tissue was suspended in deionized water. For efficient extraction, the samples were sonicated for $15 \mathrm{~min}$ in an ultrasonic water bath and then centrifuged at $12,000 \mathrm{~g}_{\mathrm{n}}$ for $5 \mathrm{~min}$. The aqueous phase was collected and filtered through two prefilled chromatography columns to remove anion (1-X8 resin; Bio-Rad Laboratories, Hercules, CA) and cation (50W-X8 resin; Bio-Rad Laboratories) contaminants. Two hundred and fifty microliters of filtered sample was transferred to a polytetrafluoroethylene filter vial (0.45 $\mu \mathrm{m}$; Restek, Bellafonte, PA) and filtered again. Twenty-five microliters of the elute was injected in IC equipped with an anion exchange column and a guard column (CarboPac MA1; Dionex, Sunnyvale, CA). An isocratic mobile phase consisting of solvent $\mathrm{A}$ and solvent $\mathrm{B}, 38.8 \%$ deionized water and $61.2 \% \mathrm{NaOH}(1 \mathrm{~N})$, respectively, at a flow rate of 0.4 $\mathrm{mL} \cdot \mathrm{min}^{-1}$ was used. For juice, a 2-mL sample was centrifuged at $12,000 g_{\mathrm{n}}$ for $5 \mathrm{~min}$. Ten microliters of the supernatant was added to $29.90 \mathrm{~mL}$ of deionized water. Ten microliters of the diluted sample was filtered through a prefilled chromatography column (1-X8 resin) to remove anion contaminates. Two hundred and fifty microliters of the filtered sample was transferred to a polytetrafluoroethylene (PTFE) filter vial $(0.45 \mu \mathrm{m}$; Restek) and filtered again. Twenty-five microliters of elute was injected in IC equipped with an anion exchange column and a guard column (CarboPac PA200, Dionex). An isocratic mobile phase consisting of solvent $\mathrm{A}, 95 \%$ deionized water, and solvent $\mathrm{B}, 5 \% \mathrm{NaOH}(1 \mathrm{~N})$, with a flow rate of $0.4 \mathrm{~mL} \cdot \mathrm{min}^{-1}$ was used. Standard curves for sucrose, fructose, glucose, and inositol were created and used for quantification.

Analysis of Gene EXPRession. Total RNA was extracted from $100 \mathrm{mg}$ of AZ-C, peels, and leaves using a modified TRIzol protocol (Chomczynski and Sacchi, 1987). TRIzol solution, prepared in the laboratory, contained $40 \%$ phenol, $0.8 \mathrm{M}$ guanidine thiocyanate, $0.4 \mathrm{M}$ ammonium thiocyanate, $0.1 \mathrm{~m}$ sodium acetate at $\mathrm{pH} 5.0$, and $5 \%$ glycerol. The quality and quantity of RNA were evaluated by a spectrophotometer (Epoch 2 Microplate; BioTek Instruments, Winooski, VT) and with denaturing formaldehyde $1.2 \%$ agarose gel (Rio, 2015). For cDNA synthesis, $1 \mu \mathrm{g}$ total RNA was first treated with DNase I (RQ1; Promega, Madison, WI) and used for first-strand synthesis using oligo $(\mathrm{dT})_{15}$ primer, dNTP mix, and reverse transcriptase (ImProm-II; Promega) in a $20-\mu \mathrm{L}$ reaction according to the manufacturer's protocol.

The relative expression of genes of interest was determined using quantitative real-time polymerase chain reaction (qPCR). Sequences were obtained from GenBank and Reference Sequences databases [National Center for Biotechnology Information (NCBI), 2018b]. To determine the involvement of ethylene in HLB-associated preharvest fruit drop, the $C$. sinensis genes encoding enzymes catalyzing the ratelimiting steps for ethylene biosynthesis, $A C S$, and $A C O$ (Liao and Burns, 2012), and an ERF1 (Cheng et al., 2015) were analyzed in AZ-C, peels, and leaves. Cellulase6 (CELO), polygalacturonase 20 (PG20), pectate lyase5 (PL5), and EXP10 were selected to be analyzed in AZ-C because their expressions were correlated with the abscission process in ethylene-treated healthy sweet orange (Cheng et al., 2015; Merelo et al., 2017). The expressions of genes related to carbohydrate metabolism, including $S B 1$, which encodes glucose-1-phosphate adenylyltransferase for starch biosynthesis and was down-regulated in the vascular tissue at the AZ-C and fruit flavedo due to HLB infection in 'Hamlin' and 'Valencia' sweet orange (Li et al., 2003a; Liao and Burns, 2012), and sucrose synthase1 (SUS1), which was up-regulated in leaves of 'Murcott' mandarin (Citrus reticulata) in response to girdling (Li et al., 2003a, 2003b), were analyzed in peels and leaves. The current study also reported the transcript levels of leaf sucrose transporter 1 (SUT1) and peel sucrose transporter 2 (SUT2), which are expressed strongly in sugar exporting and importing organs, respectively (Li et al., 2003c). Gene-specific primers were designed using Primer BLAST (NCBI, 2018a). The sequences of primers are listed in Table 1.

A real-time PCR system (7500 Fast Real-Time PCR System; Applied Biosystems, Foster City, CA) was used to perform qPCR in a $10-\mu \mathrm{L}$ reaction system containing $10 \mathrm{ng}$ of RNA, 300 nM forward and reverse primers, and SYBR green reagent mix [VeriQuest SYBR Green qPCR Master Mix (2X); Affymetrix, Cleveland, $\mathrm{OH}$ ]. Each reaction was performed at $50{ }^{\circ} \mathrm{C}$ for $2 \mathrm{~min}$ and $95^{\circ} \mathrm{C}$ for $10 \mathrm{~min}$, followed by 40 cycles of $95^{\circ} \mathrm{C}$ for $15 \mathrm{~s}$ and $60{ }^{\circ} \mathrm{C}$ for $60 \mathrm{~s}$. Dissociation-curve analysis ranging from 60 to $95{ }^{\circ} \mathrm{C}$ was performed at the end of each qPCR to confirm that nonspecific products were not formed.

Using the quantification cycle, the levels of relative expression (fold change) of genes of interest were calculated using the Pfaffl method (Hellemans et al., 2007; Pfaffl, 2001), with actin and the gene for a DIM1 homolog/YLS8 (DIM1) as the reference genes (Mafra et al., 2012, 2013). Gene expression data for each sampling date were the mean of four biological replicates; each biological replicate was the mean of two qPCR (technical) replicates.

Statistical Analysis. Two-way analysis of variance (ANOVA) was used to determine the effects of fruit types (tight or loose fruit), symptom levels of trees (mild, moderate, or severe), and their interaction with fruit and leaf characteristics, juice and leaf carbohydrate levels, and relative gene expressions using the General Linear Model procedure of SAS (version 9.3; SAS Institute, Cary, NC). When ANOVA testing indicated significant differences, post hoc comparisons were performed using Tukey's honestly significant difference procedure with a family error rate of $\alpha \leq 0.05$. Pearson's correlation coefficients were calculated to identify significant relationships $(P \leq 0.05)$ between $\mathrm{FT}$ values and fruit weight and size and target gene expression levels.

\section{Results}

Fruit DRoP RATE AND FRUIT DETACHMENT FORCE. In the beginning of the survey in January, mild, moderate, and severe trees had similar fruit drop rate $[6 \%, 8 \%$, and $11 \%$, respectively (Fig. 1)]. For both mild and moderate trees, the drop rate increased steadily; however, there was no apparent difference in the drop rate between these two types of trees from January through May. In contrast, starting in February, 3 months before harvest, the fruit drop rate increased markedly for severe trees, which was greater than trees at the other symptom levels. At the end of the survey period (just before harvest in May), severe trees had a 74\% total fruit drop rate, whereas the drop rate for mild and moderate trees were $45 \%$ and $42 \%$, respectively.

Three weeks before harvest, 10 randomly selected fruit from each tree were subjected to FT measurements to determine the likeliness of fruit drop (loose vs. tight fruit on trees). Although mild trees had $13 \%$ loose fruit, there were $60 \%$ loose fruit for 
Table 1. Gene-specific primer sequences for gene expression analysis of 'Valencia' sweet orange with quantitative real-time polymerase chain reaction.

\begin{tabular}{|c|c|c|c|c|}
\hline Gene & Description & Accession no. & $\begin{array}{l}\text { Forward and reverse primer sequences } \\
\qquad\left(5^{\prime} \text { to } 3^{\prime}\right)\end{array}$ & $\begin{array}{l}\text { Amplicon } \\
\text { size (bp) }\end{array}$ \\
\hline \multirow[t]{2}{*}{$\overline{S B 1}$} & \multirow[t]{2}{*}{ Glucose-1-phosphate adenylyltransferase } & \multirow[t]{2}{*}{ NM_001288894.1 } & TACAGGCTTATAGACATCCC & \multirow[t]{2}{*}{129} \\
\hline & & & GGTACCATTCCCGAAATATG & \\
\hline \multirow[t]{2}{*}{ SUS1 } & \multirow[t]{2}{*}{ Sucrose synthase 1} & \multirow[t]{2}{*}{ AB022092.1 } & ACAGCGATGTTGAGAATAAG & \multirow[t]{2}{*}{129} \\
\hline & & & САТTCTTTCСАТАССАСТСС & \\
\hline \multirow[t]{2}{*}{ SUT1 } & \multirow[t]{2}{*}{ Sucrose transporter 1} & \multirow[t]{2}{*}{ AY098891.1 } & CGAGATATTTGGTGCATTGA & \multirow[t]{2}{*}{110} \\
\hline & & & AATCAGTGTCGAACAACAAG & \\
\hline \multirow[t]{2}{*}{ SUT2 } & \multirow[t]{2}{*}{ Sucrose transporter 2} & \multirow[t]{2}{*}{ AY098894.1 } & GCTTTCTCTATTGACTCCTTAC & \multirow[t]{2}{*}{130} \\
\hline & & & GCATTTATCACTCCAGATACC & \\
\hline \multirow[t]{2}{*}{ CEL6 } & \multirow[t]{2}{*}{ Cellulase 6} & \multirow[t]{2}{*}{ NM_001288865.1 } & CCAAGTACCTTAGCTCAAATG & \multirow[t]{2}{*}{119} \\
\hline & & & AGCTGGATTATCGCCTAATA & \\
\hline \multirow[t]{2}{*}{$P G 20$} & \multirow[t]{2}{*}{ Polygalacturonase 20} & \multirow[t]{2}{*}{ XM_006483616.2 } & TGTTCGAGCTACCGATATTA & \multirow[t]{2}{*}{120} \\
\hline & & & CCTGAAAGTCTTGCTCTATTC & \\
\hline \multirow[t]{2}{*}{ PL5 } & \multirow[t]{2}{*}{ Pectate lyase 5} & \multirow[t]{2}{*}{ XM_006483937.2 } & GGGATTTGATGGTAAATGGT & \multirow[t]{2}{*}{121} \\
\hline & & & CCTGCTGTGATTGAACTTAT & \\
\hline \multirow[t]{2}{*}{ EXP10 } & \multirow[t]{2}{*}{ Expansin A10 } & \multirow[t]{2}{*}{ XM_006483070.2 } & ССТСТСТСТСТТТСТСТАСТС & \multirow[t]{2}{*}{120} \\
\hline & & & GCCTCCATTAGCATGAAC & \\
\hline \multirow[t]{2}{*}{$A C S$} & 1-aminocyclopropane-1-carboxylate synthase & NM_001288944.2 & CAAGCTTCTCTAGCCATAAC & 92 \\
\hline & & & GACAAGATTCCCATTGTCTC & \\
\hline$A C O$ & 1-aminocyclopropane-1-carboxylate oxidase & XM_006475390.2 & AGATGGAGAGTGGGTAAAG & 177 \\
\hline & & & GCATCGTTAGCAGGATTATAG & \\
\hline ERF1 & Ethylene-responsive transcription factor 1 & NM_001320065.1 & GCTGTAGGGTCACAATTATC & 113 \\
\hline & & & CACCAAATAGTAGCAGTAGC & \\
\hline$A C T$ & Actin 7 & XM_006464503.2 & GTTGGTTGACATGGAGAAG & 121 \\
\hline & & & GACGGTTGAGTACAGAAATAAG & \\
\hline DIMI & Thioredoxin-like protein YLS8 & XM_006484463.2 & CGAAACCTGTATGCAGATGG & 138 \\
\hline & & & ACGGTTGAGGGATCGTAAAG & \\
\hline
\end{tabular}

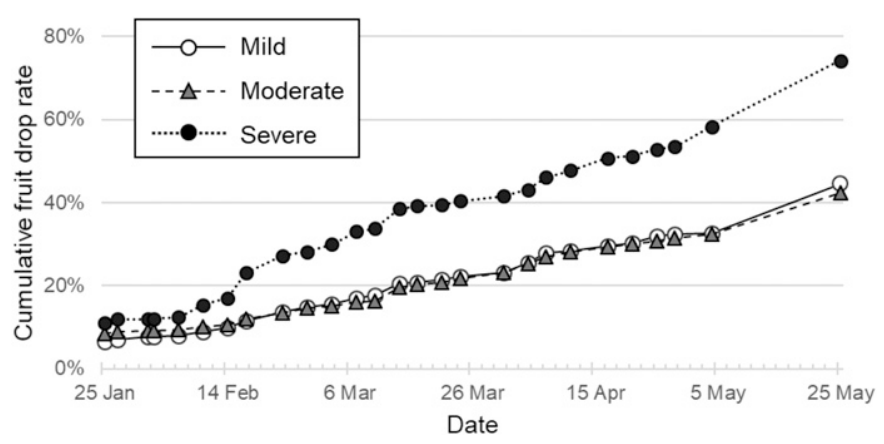

Fig. 1. Cumulative fruit drop rate of 'Valencia' sweet orange trees with three Huanglongbing symptom levels (mild, moderate, and severe).

severe trees (Fig. 2). For moderate trees, 38\% of fruit were loose, intermediate between mild and severe trees. Therefore, these results indicated that the percentage of loose fruit increased with the increase in HLB severity. In general, the majority of fruit of mild trees were green, whereas the peel color of fruit from moderate and severe trees was yellow at the time of collection (Supplemental Fig. 1). Nevertheless, there was no obvious difference in peel color for tight fruit and loose fruit (irrespective of HLB severity).

Fruit CHARACTERISTICS AND JUICE QUALITY. The numbers of healthy leaves, blotchy mottled leaves, and total leaves on the branch above the fruit were not significantly different between the two fruit types or among the three symptom levels (Table 2). Consistently, there was no significant difference in the area of the total source leaves (for one fruit) (Table 2).
There were no fruit type and tree symptom interactions related to fruit size or weight (Fig. 3). Tight fruit had an average size of $65.9 \mathrm{~mm}$ and an average weight of $162.5 \mathrm{~g}$, which were significantly greater than those of loose fruit (62.6 $\mathrm{mm}$ and $138.9 \mathrm{~g})$. The FT values were significantly (positively) correlated with fruit size $(r=0.46 ; P<0.001)$ and fruit weight $(r=0.47 ; P<0.001)$. Interestingly, the tree symptom level had a significant effect on fruit size and weight. The size and weight of fruit from mild trees $(65.4 \mathrm{~mm}$ and $160.5 \mathrm{~g})$ and moderate trees $(66.4 \mathrm{~mm}$ and $165.0 \mathrm{~g})$ were significantly greater than fruit from severe trees $(61.3 \mathrm{~mm}$ and $129.3 \mathrm{~g})$. There was a negative correlation between the symptom rating and fruit size $(r=-0.47 ; P=0.023)$ and weight $(r=-0.62 ; P=0.003)$. The numbers of healthy seeds, aborted (shriveled) seeds, and total seeds (the sum of healthy and aborted seeds) per fruit were not significantly different between the two fruit types or among the three symptom levels (Table 2).

There was no significant difference in the content of TSS or TA in juice of tight fruit compared to loose fruit (Fig. 4). Juice TSS content was significantly greater in the fruit of severe trees than mild trees, with that of moderate trees being intermediate between the two. However, among the three symptom levels, no difference in TA was observed. The ratio of TSS to TA, an index of fruit maturity that is used commercially, for all combinations of fruit types and symptom levels was more than 10 (data not shown), indicating that all fruit reached legal maturity at the time of collection by Florida industry standards (Kimball, 1991). Despite the significant differences in TSS contents among symptom levels, the ratio of TSS to TA was not significantly different among the symptom levels or between fruit types. 


\section{Ratio of loose and tight fruit number}

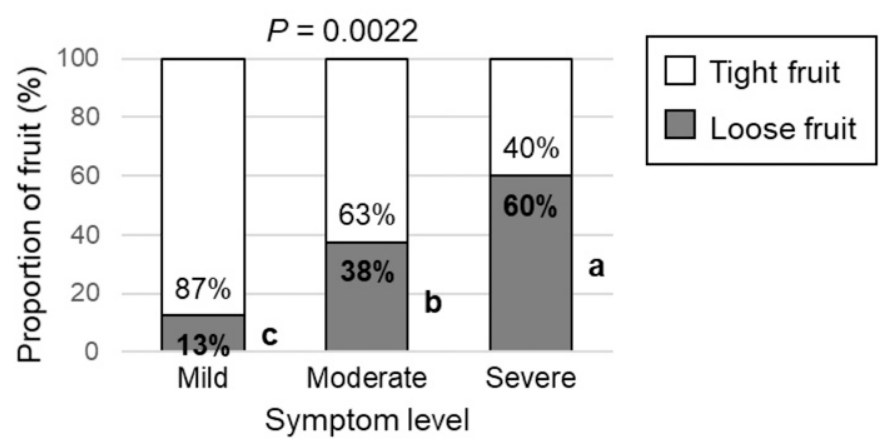

Fig. 2. The percentages of tight and loose fruit (fruit detachment force $>6$ and $\leq 6 \mathrm{kgf}$, respectively) collected 3 weeks before harvest from 'Valencia' sweet orange trees with three Huanglongbing symptom levels (mild, moderate, and severe). Data are means of four biological replicates. Different letters indicate significant difference via Tukey's honestly significant difference test.

JUICE AND LEAF CARBOHYDRATES. Among fruit types and symptom levels, no significant difference in the concentration of sucrose in juice was found (Fig. 4). Additionally, there was no interaction effect of the two factors (fruit type $\times$ tree symptom level) on sucrose concentration. In contrast, fruit types and symptom levels had interactive effects on the concentrations of fructose, glucose, and inositol in juice (Fig. 4). Among all combinations of fruit types and symptom levels, loose fruit of severe trees had the greatest concentrations of fructose and glucose in juice. Similarly, the inositol concentration was significantly greater in loose fruit of severe trees than other combinations.

There was no fruit type $\times$ tree symptom level interaction for or significant effect of the fruit type on the content of sucrose, fructose, glucose, and inositol in source leaves (Fig. 5). Among the three symptom levels, no differences in the leaf sucrose and glucose levels were observed. However, leaves of severe trees had significantly greater fructose and inositol contents than did those of mild trees, respectively, with those of moderate trees being similar to mild trees.

EXPRESSION OF CARBOHYDRATE METABOLISM GENES IN PEEL AND LEAVES. Significant interaction effects of the fruit types and tree symptom levels did not occur for the expression of any genes of interest in any tissues investigated in this study. Peel $S B 1$ and SUT2 transcripts and leaf SUS1, SB1, and SUT1 transcripts were not significantly different between the two fruit types or among the three symptom levels (Fig. 6).

EXPRESSION OF CELL WALL MODIFICATION GENES IN CALYX ABSCISSION ZONES. In AZ-C, the levels of CEL6, PG20, PL5, and EXP10 transcripts were greater for loose fruit compared with tight fruit (Fig. 7). The values of FT were also strongly and negatively correlated with the expressions of CEL6 $(r=-0.73$; $P<0.001), P G 20(r=-0.72 ; P<0.001), P L 5(r=-0.42 ; P=$ $0.059)$, and $\operatorname{EXP10}(r=-0.45 ; P=0.037)$. Expressions of these genes together explained $64 \%$ of the variation in the values of FT $[$ FT value $=7.94-0.38 \times(C E L 6$ expression $)+0.10 \times(P G 20$ expression $)-0.15 \times(P L 5$ expression $)-0.08 \times(E X P 10$ expression); $\left.r^{2}=0.64 ; P=0.003\right]$.

The transcript levels of CEL6, PG20, and PL5 were not significantly different in AZ-C of mild, moderate, and severe trees, respectively. Expression of EXP10 in severe trees was significantly greater than moderate trees, but similar to that in mild trees. Furthermore, there was no significant correlation between the visual symptom ratings and CEL6, PG20, PL5, or EXP10 expression levels, suggesting that HLB severity does not affect the expression of cell wall hydrolytic genes.

EXPRESSION OF ETHYLENE BIOSYNTHETIC AND RESPONSIVE GENES. For the three tissues analyzed herein, the transcript levels of $A C S$ and $A C O$ were not significantly different between tight and loose fruit; however, $A C S$ expression in peels and $A C O$ expression in $\mathrm{AC}-\mathrm{Z}$ had greater levels in loose fruit than in tight fruit (Fig. 8). With the exception of $A C S$ expression in leaves, there was no significant difference in $A C S$ and $A C O$ expression levels in any tissues of mild, moderate, and severe trees. Leaf $A C S$ expression was significantly greater in mild trees compared with severe trees; leaves of moderate trees expressed $A C S$ at an intermediate level between that of mild and severe trees.

Regardless of tissues, ERF1 expression was similar between the two fruit types (Fig. 8). Nevertheless, the effects of symptom levels on the ERF1 expression patterns were similar among AZ-C, peels, and leaves. In all three tissues, the transcript levels of ERF1 were the greatest for mild trees, followed by moderate trees, with the lowest for severe trees.

\section{Discussion}

For HLB-affected 'Valencia' sweet orange, the drop rate of mature fruit was higher for trees with severe symptoms than for trees with mild or moderate symptoms from February through harvest in May (Fig. 1). Similar to the observations of the whole tree, at 3 weeks before harvest, severe trees had a higher percentage of fruit that were likely to abscise (loose fruit) compared with mild and moderate trees (Fig. 2). The results suggest that preharvest fruit drop is exacerbated with the progression of HLB severity. This is in agreement with the results released by the USDA (2018), which indicated an increase in fruit drop rates for sweet oranges in Florida during the past decade as HLB has become an epidemic. The current research also documented an inverse relationship between HLB symptom levels exhibited by trees and the fruit size and weight (Fig. 3). A reduction in the size of fruit of HLB-affected sweet orange trees compared with healthy (CLas-negative) trees has been reported (Baldwin et al., 2018; Bové, 2006; Liao and Burns, 2012; Spann and Oswalt, 2008). Consistently, for HLBaffected 'Valencia' sweet orange trees, mature fruit from the branches showing HLB symptoms were smaller (in weight, diameter, and volume) than fruit from asymptomatic trees (Rosales and Burns, 2011). Interestingly, regardless of the symptom level of trees, loose fruit were smaller and lighter than tight fruit (Fig. 3), indicating that the higher tendency of loose fruit to drop is not due to greater mass. The growth of citrus fruit is predominantly due to cell division and expansion during stages I and II of fruit development, respectively (Ferguson and Grafton-Cardwell, 2014; Iglesias et al., 2007). For citrus, relatively slow-growing fruit tend to drop at an early stage of development, whereas fast-growing fruit have greater potential to survive through harvest (Ferguson and Grafton-Cardwell, 2014). These phenomena, taken together with the results of this study, suggest the possibility that the likeliness of fruit drop before harvest might be determined much earlier before they reach maturity, and as early as stage I or stage II of fruit development and growth. Rosales and Burns (2011) provided evidence that the overall small size of mature fruit on 
Table 2. Leaf and seed characteristics of tight and loose fruit (fruit detachment force $>6$ and $\leq 6 \mathrm{kgf}$, respectively) of 'Valencia' sweet orange trees with mild, moderate, and severe Huanglongbing symptoms.

\begin{tabular}{|c|c|c|c|c|c|c|c|c|}
\hline \multirow{2}{*}{$\begin{array}{l}\text { Symptom } \\
\text { level (SL) }\end{array}$} & \multirow[b]{2}{*}{ Fruit type (FT) } & Healthy leaves $^{z}$ & Blotchy mottled leaves & Total leaves & \multirow{2}{*}{$\begin{array}{l}\text { Leaf area } \\
\left(\mathrm{cm}^{2} / \text { fruit }\right)^{\mathrm{y}}\end{array}$} & Healthy seeds & Aborted seeds & Total seeds \\
\hline & & & (no./fruit) & & & \multicolumn{3}{|c|}{ (no./fruit) } \\
\hline Mild & Tight & $5.8^{\mathrm{x}}$ & 1.7 & 7.5 & 74.2 & 7.0 & 1.1 & 8.2 \\
\hline Mild & Loose & 6.5 & 1.3 & 7.8 & 71.5 & 6.8 & 0.7 & 7.5 \\
\hline Moderate & Loose & 5.6 & 2.2 & 7.8 & 85.5 & 7.8 & 0.9 & 8.7 \\
\hline Severe & Tight & 5.8 & 1.5 & 7.3 & 43.2 & 5.0 & 1.4 & 6.4 \\
\hline Severe & Loose & 4.3 & 2.0 & 6.3 & 45.2 & 6.2 & 1.4 & 7.5 \\
\hline & $\mathrm{FT} \times \mathrm{SL}$ & NS & NS & NS & NS & NS & NS & NS \\
\hline & FT & NS & NS & NS & NS & NS & NS & NS \\
\hline & SL & NS & NS & NS & NS & NS & NS & NS \\
\hline
\end{tabular}

${ }^{\mathrm{z}}$ Leaves were quantified based on the branch above the fruit.

${ }^{y}$ Leaf area was the sum of the area of all leaves on the branch above the fruit.

${ }^{\mathrm{x}}$ Data are means of four biological replicates; NS = not significantly different.

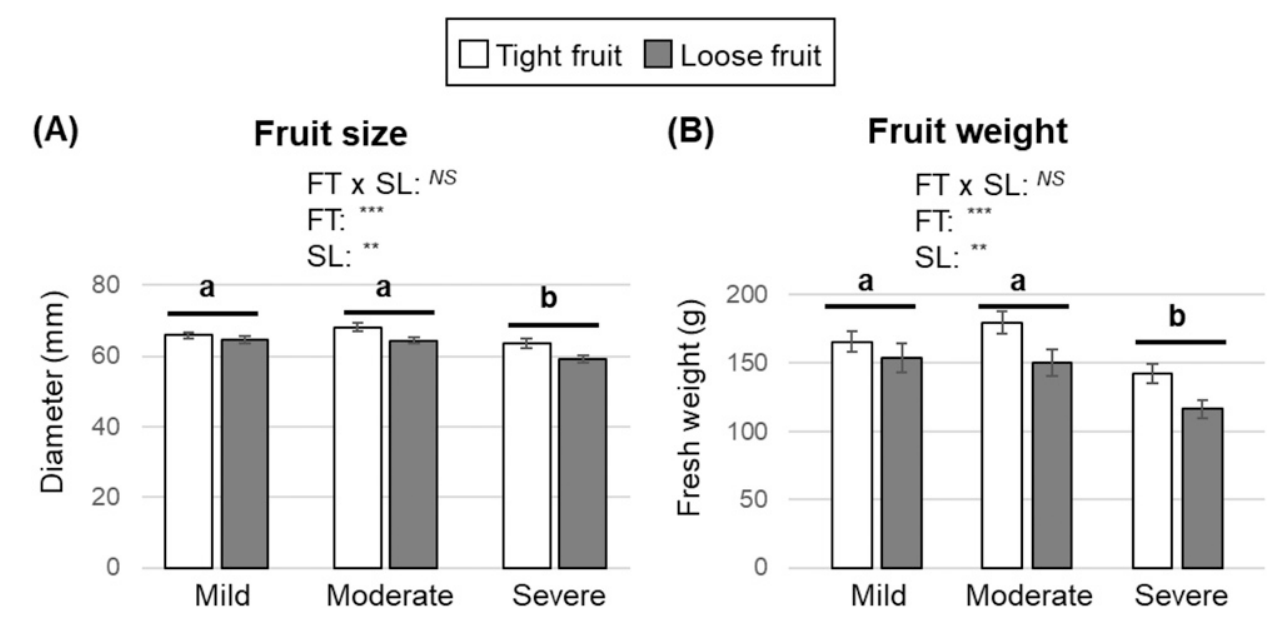

Fig. 3. The diameter and fresh weight of two fruit types [fruit detachment force (FT) $>6 \mathrm{kgf}$ (tight) and $\leq 6 \mathrm{kgf}$ (loose)] of 'Valencia' sweet orange trees with three Huanglongbing symptom levels [SL (mild, moderate, and severe)]. Data are means \pm SE of four biological replicates. Different letters indicate significant difference via Tukey's honestly significant difference test. NS = not significantly different.

symptomatic branches of HLB-affected trees was due to the low number of hypodermal cells, rather than reduced cell size, in peels, further suggesting the suppression of cell division by HLB. How HLB affects this process is still unclear. Given that $C$ Las infection resulted in altered levels of endogenous hormones in immature fruit and leaves of sweet orange trees (Martinelli et al., 2012; Nehela et al., 2018), it is possible that cell division and/or expansion are impeded in response to HLBinduced changes in hormone homeostasis. Within HLBaffected trees, the uneven distribution of CLas (Folimonova et al., 2009) likely causes varying degrees of effects on growth among fruit, which may explain why one population of fruit was loose and others were categorized as tight fruit on individual trees in this study.

Notably, the levels of TSS, sucrose, fructose, glucose, and inositol in juice of loose fruit were either the same or greater than those of tight fruit (Fig. 4). That is, loose fruit did not accumulate less carbohydrates compared with tight fruit, suggesting that preharvest fruit drop in HLB-affected citrus trees is not due to the shortage of carbohydrates in fruit, which is the dominant cause of June drop (Goldschmidt, 1999;
Goldschmidt and Koch, 1996; Goldschmidt and Monselise, 1977; Gómez-Cadenas et al., 2000; Ruiz et al., 2001). Consistently, the number and total area of source leaves for individual fruit, which were composed of mature leaves on a 20-cm-long branch (Koch and Avigne, 1984), were similar for loose and tight fruit (Table 2). In addition, there was no significant difference between the two types of fruit regarding sugar content in source leaves (Fig. 5) or regarding the expression of genes related to the synthesis, loading, and unloading of carbohydrates in peels or leaves (Fig. 6). These results suggest that carbohydrate availability at the source, at least at the time of collection, was not different between tight and loose fruit, thereby lending support to the interpretation that carbohydrate limitation is not the predominant cause of preharvest fruit drop for HLB-affected trees. Fruit drop in citrus can be induced by stress conditions, such as water deficiency, nutrient deficiency, high temperatures, and high salinity (Iglesias et al., 2007). For HLB-affected 'Valencia' sweet orange on 'Swingle' citrumelo rootstock, a decline in root density occurred in trees with foliar symptoms compared with asymptomatic trees, suggesting that water and nutrient uptake might be restricted for symptomatic trees (Johnson et al., 2014). Therefore, it is possible that, despite uninterrupted irrigation and fertilization, the sweet orange trees in this study might have been subjected to water-deficit and/or nutrientdeficit stress as a result of root loss caused by HLB in combination with the warm spring temperatures in Florida, thereby leading to increased fruit drop before harvest. If this possibility is confirmed to be true, then, given the results reported herein demonstrating fruit drop rates and increased loose fruit percentages associated with the symptom level of trees, symptoms of the canopy might be an indicator of the degree of root damage. 


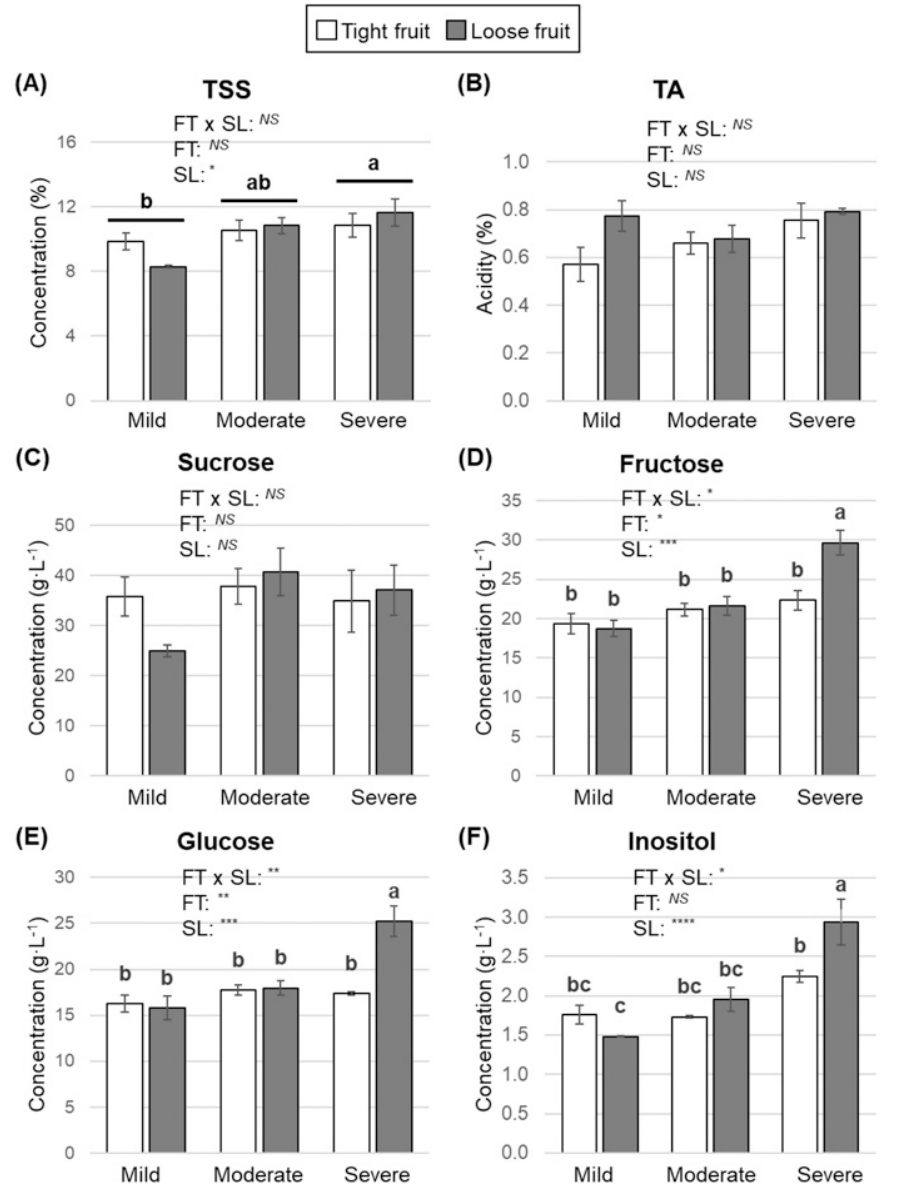

Fig. 4. The levels of total soluble solids (TSS), titratable acid (TA), and levels of sucrose, fructose, glucose, and inositol in juice of two fruit types [fruit detachment force (FT) $>6 \mathrm{kgf}$ (tight) and $\leq 6 \mathrm{kgf}$ (loose)] of 'Valencia' sweet orange trees at three Huanglongbing symptom levels [SL (mild, moderate, and severe)]. Data are means \pm SE of four biological replicates. Different letters indicate significant difference via Tukey's honestly significant difference test. $\mathrm{NS}=$ not significantly different.

Interestingly, the concentrations of glucose, fructose, and inositol in juice of loose fruit were greater for severe trees than loose fruit of mild and moderate trees; however, symptom levels did not affect the carbohydrate concentrations in the juice of tight fruit (Fig. 4). Similarly, Baldwin et al. (2018) reported that for 'Valencia' sweet orange, mature fruit of HLB-affected trees that dropped after vigorous shaking had greater concentrations of glucose and fructose in juice compared with the dropped fruit of healthy (CLas-negative) trees and fruit that remained on HLB-affected and healthy trees, respectively, following shaking. In contrast to the observations of 'Valencia' sweet orange, early-maturing 'Hamlin' sweet orange, which also has a high drop rate for mature fruit before harvest, did not exhibit a clear trend of juice carbohydrate concentrations among different kinds of fruit (Baldwin et al., 2018). Whether the particular interaction between fruit type (loose fruit) and symptom level (severe trees) for juice carbohydrates is cultivarspecific and related to preharvest fruit drop or other HLBassociated physiological changes of trees remains unclear.

In the model plants, Arabidopsis, and tomato (Solanum lycopersicum), endogenous ethylene plays a key role in the acceleration of floral organ and leaf abscission by activating

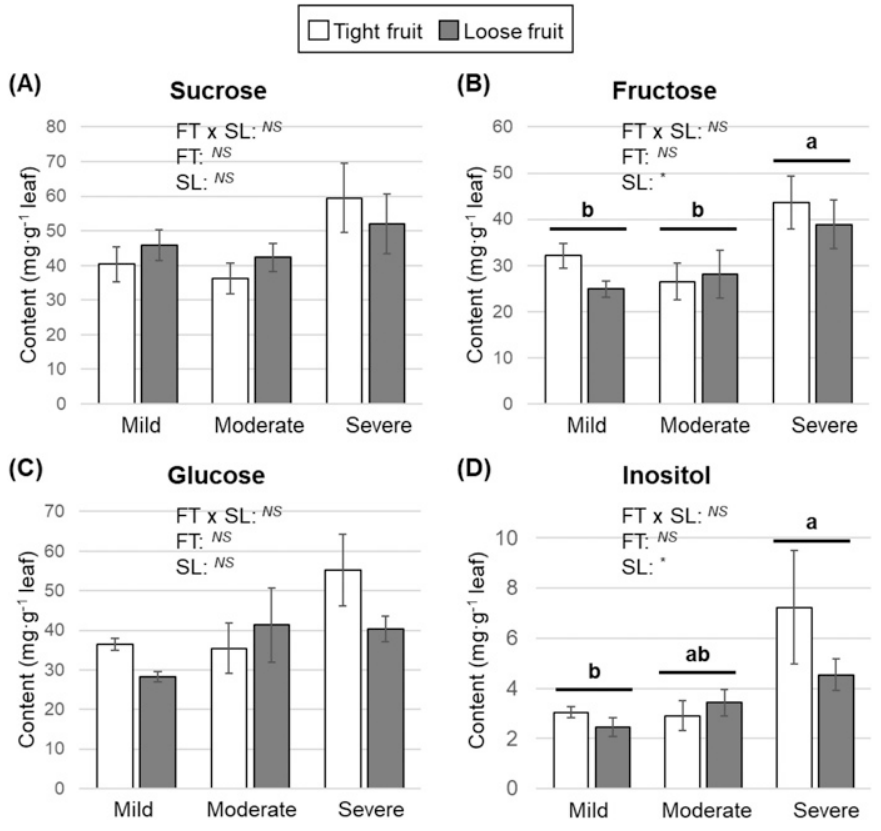

Fig. 5. The levels of sucrose, fructose, glucose, and inositol in leaves of two fruit types [fruit detachment force (FT) $>6 \mathrm{kgf}$ (tight) and $\leq 6 \mathrm{kgf}$ (loose)] of 'Valencia' sweet orange trees with three Huanglongbing symptom levels [SL (mild, moderate, and severe)]. Data are means \pm SE of four biological replicates. Different letters indicate significant difference via Tukey's honestly significant difference test. NS = not significantly different.

cell wall hydrolytic enzymes to dissolve middle lamella; therefore, cell wall modification allows the separation of cells at the distal and proximal sides of AZ (González-Carranza et al., 2002, 2007; Kim, 2014; Patharkar and Walker, 2018; Patterson, 2001; Taylor et al., 1991). In citrus, it has been demonstrated that the shortage in carbohydrates triggers the abscission of fruitlets (June drop) through increasing the level of ethylene produced in fruit (Gómez-Cadenas et al., 2000). By using exogenously applied ethylene and ethylene action inhibitor, a number of studies have provided evidence that, for healthy sweet orange trees, ethylene-induced abscission of mature fruit also involves up-regulation of the activity of hydrolytic enzymes as well as the expression of genes encoding these enzymes, including cellulase, PG, PL, PME, and members of the EXP transcription family (Burns and Lewandowski, 2000; Burns et al., 2000; Cheng et al., 2015; Goren and Huberman, 1976; Merelo et al., 2017). The results of this research demonstrated that ethylene biosynthesis genes $A C S$ and $A C O$ were not differentially expressed in any tissues of loose fruit compared with tight fruit, except for greater transcript levels of peel $A C S$ and AZ-C $A C O$ in loose fruit. There was no significant difference in the expression of $E R F 1$, a transcription factor that regulates genes in response to ethylene (Guo and Ecker, 2004), analyzed in AZ-C, peels, or leaves of both types of fruit. Although the results cannot provide evidence that ethylene biosynthesis was up-regulated and cannot suggest that ethylene-dependent responses were activated in loose fruit, the expression levels of cell wall hydrolytic genes CEL6, PG20, PL5, and EXP10 were greater in the AZ-C of loose fruit (Fig. 7). This result strongly suggests that cell wall modification was occurring in the AZ-C of loose fruit during the time of collection, thereby leaving open the possibility that signal transduction involving 
SB1 in peel

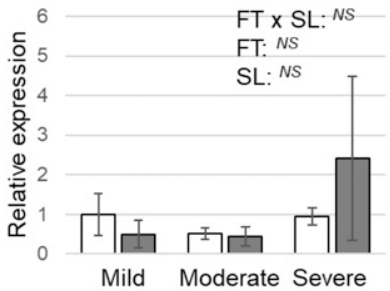

SUS1 in leaf

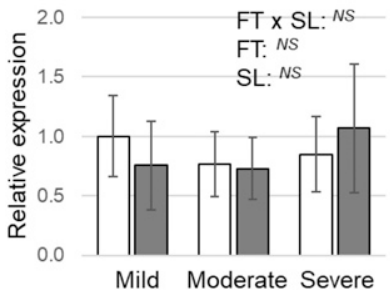

SUT2 in peel

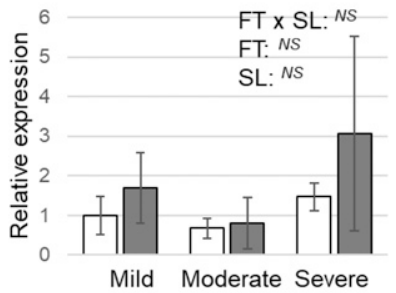

SB1 in leaf

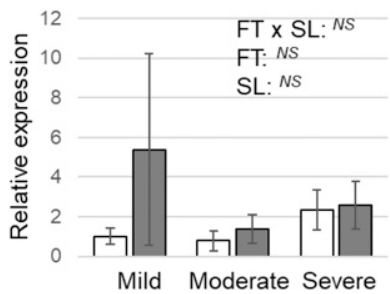

$\square$ Tight fruit $\square$ Loose fruit

SUT1 in leaf

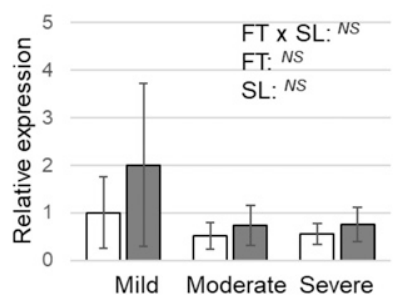

Fig. 6. Expression of carbohydrate metabolism genes encoding glucose-1-phosphate adenylyltransferase large subunit ( $S B 1$ ) and sucrose transporter 2 ( $S U T 2$ ) in the peel and sucrose synthase ( $S U S 1), S B 1$, and sucrose transporter 1 (SUT1) in the leaves of two fruit types [fruit detachment force (FT) $>6 \mathrm{kgf}$ (tight) and $\leq 6 \mathrm{kgf}$ (loose)] of 'Valencia' sweet orange trees with three Huanglongbing symptom levels [SL (mild, moderate, and severe)]. Data are means \pm SE of four biological replicates. NS $=$ not significantly different.

\section{$\square$ Tight fruit $\square$ Loose fruit}

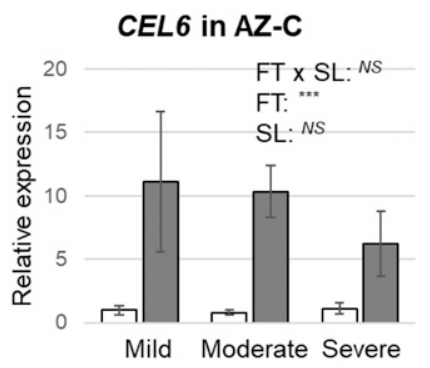

PL5 in AZ-C

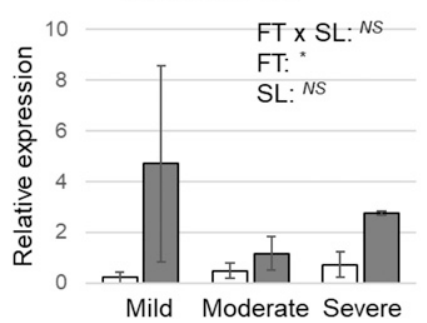

$P G 20$ in AZ-C

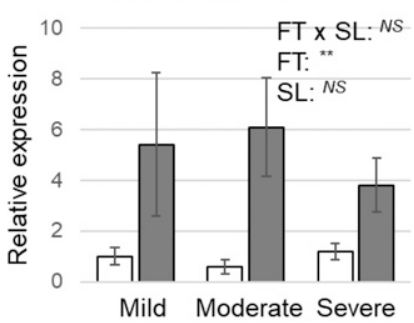

EXPA10 in AZ-C

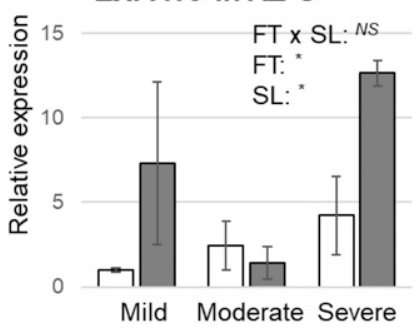

Fig. 7. Expression of cellulase6 (CELO), polygalacturonase 20 (PG20), pectate lyase 5 (PL5), and expansin10 (EXP10) in the calyx abscission zone (AZ-C) of two fruit types [fruit detachment force (FT) $>6 \mathrm{kgf}$ (tight) and $\leq 6 \mathrm{kgf}$ (loose)] of 'Valencia' sweet orange trees with three Huanglongbing symptom levels [SL (mild, moderate, and severe)]. Data are means \pm SE of four biological replicates. Different letters indicate significant difference via Tukey's honestly significant difference test. NS = not significantly different.

ethylene that activates the abscission process might have occurred before the sampling day.

In Arabidopsis, an ethylene-independent pathway for abscission has been proposed for the expression of cell wall hydrolytic genes, and floral organ abscission still occurred in ethylene-insensitive mutants (Bleecker and Patterson, 1997; Patterson and Bleecker, 2004). The activity of HAESA, a protein kinase that regulates floral organ abscission, was also documented to be independent of ethylene signal transduction in Arabidopsis and tomato (Cho et al., 2008; Jinn et al., 2000; Wang et al., 2013). Therefore, if the signal transduction pathways for abscission of floral organs in the model plants and for mature fruit abscission in sweet orange are conserved, then the results of this research cannot preclude the alternative possibility that HLB can increase preharvest fruit drop in citrus independent of ethylene in addition to via the ethylenedependent pathway. Overall, our results suggested that the mechanism of fruit abscission associated with HLB is similar to that induced by exogenous ethylene in healthy citrus trees regarding cell expansion and separation at the AZ-C (Burns and Lewandowski, 2000; Burns et al., 2000; Cheng et al., 2015; Goren and Huberman, 1976; Merelo et al., 2017); however, they are insufficient to confirm the role of endogenous ethylene in HLB-related preharvest fruit drop. To clarify this, a timeline of the changes in the endogenous ethylene level in relation to the development of loose fruit needs to be established. Such a study can be challenging; nevertheless, it is necessary because of the lack of approaches to predict the potential of individual fruit to abscise before harvest.

The results reported herein demonstrated that expressions of $A C S$ and $A C O$ in the tissues analyzed were unaffected by the levels of HLB symptoms of trees, with the exception of $A C S$ expression in leaves, which exhibited a decreasing pattern with an increase in HLB symptoms (Fig. 8). The same expression pattern related to HLB severity occurred for ERF 1 transcripts in AZ-C, peels, and leaves, indicating ostensibly greater ethylene responses in tissues of less symptomatic trees compared with trees with more severe HLB symptoms. Similarly, low production of ethylene was observed in mature fruit of HLBaffected (CLas-positive) trees that showed symptoms compared with those of CLas-negative 'Valencia' sweet orange trees (Rosales and Burns, 2011). It should be noted that in contrast to the yellow peel color of the fruit of severe trees, the majority of fruit of mild trees remained green (Supplemental Fig. 1), indicating that color break for the fruit of mild trees had not completed by the time of sampling, even though they had 


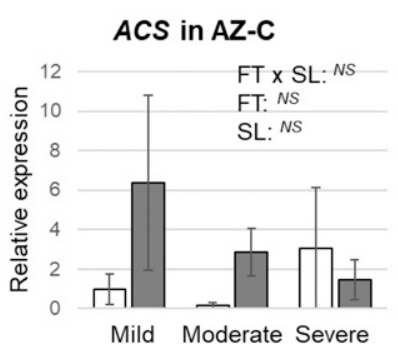

$A C O$ in AZ-C

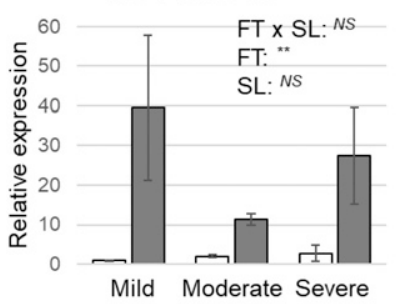

ERF1 in AZ-C

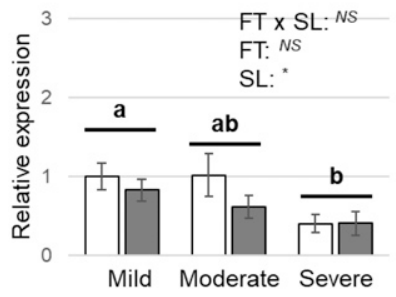

ACS in peel

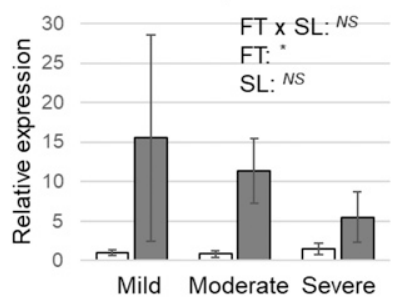

$A C O$ in peel

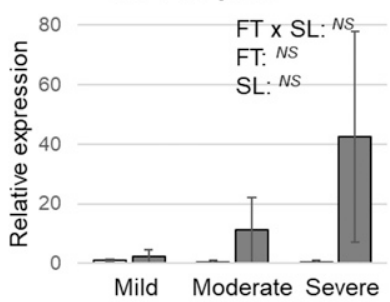

ERF1 in peel

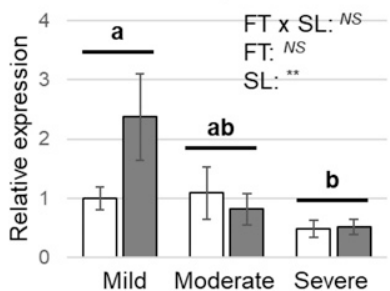

$A C S$ in leaf

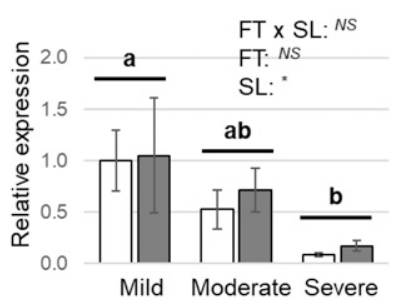

ACS in leaf

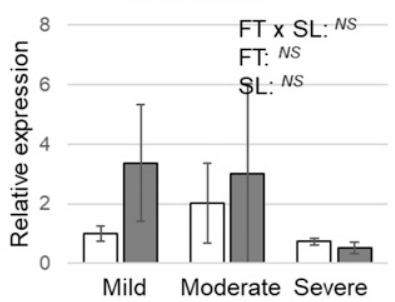

ERF1 in leaf

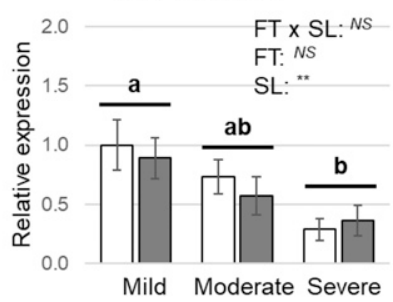

Fig. 8. Expression of genes encoding 1-aminocyclopropane-1-carboxylate (ACC) synthase (ASC), ACC oxidase (ACO), and ethylene-responsive transcription factor 1 (ERF1) in the calyx abscission zone (AZ-C), peel, and leaf of two fruit types [fruit detachment force (FT) $>6 \mathrm{kgf}$ (tight) and $\leq 6 \mathrm{kgf}$ (loose)] of 'Valencia' sweet orange trees with three Huanglongbing symptom levels [SL (mild, moderate, and severe)]. Data are means \pm SE of four biological replicates. Different letters indicate significant difference via Tukey's honestly significant difference test. NS = not significantly different.

reached legal maturity. The de-greening of peel for mature citrus fruit requires ethylene for chlorophyll degradation (Goldschmidt et al., 1993; Porat et al., 1999); therefore, the results of the current study imply the higher demand for ethylene activity to occur during this process in the fruit of mild trees at the time of collection compared with the fruit of severe trees.

Although the relationship between endogenous ethylene and HLB-associated preharvest fruit drop remains inconclusive, the results of the current study presented the possibility that ethylene production and signaling might occur before the initiation of cell wall modification. It is worth noting that other hormones may be involved in the regulation of fruit abscission. For example, the application of a synthetic auxin reduced fruitlet abscission in healthy 'Shamouti' sweet orange and 'Okitus' Satsuma mandarin (Citrus unshiu) (Agustí et al., 2002; Goren and Huberman, 1976). Additionally, for 'Hamlin' sweet orange trees, FT was decreased and the total drop rate of mature fruit was increased when treated with methyl jasmonate (Hartmond et al., 2000; Kender et al., 2001). Nevertheless, for citrus trees affected by HLB in Florida, the effects of plant growth regulators on mature fruit abscission are not always consistent; therefore, their use is not recommended to manage HLB-associated preharvest fruit drop (Albrigo and Stover, 2015). The results reported herein suggest that the severity of HLB, with regard to the visual symptom levels of the tree, is associated with negative effects on citrus fruit growth, size and weight of fruit at maturity, and the rate of preharvest fruit drop. More importantly, the results of this research provided the first striking evidence that, in contrast to June drop, carbohydrate shortage in fruit is not the predominant cause of increased mature fruit drop for HLB-affected citrus trees. Because adverse conditions can stimulate fruit drop in citrus (Iglesias et al., 2007), it is possible that HLB impairs roots and/or other tissues, thereby subjecting affected trees to the stresses that lead to inhibited fruit development and increased fruit drop. This possibility must be verified so that strategies to mitigate increased preharvest fruit drop associated with HLB can be developed.

\section{Literature Cited}

Agustí, M., S. Zaragoza, D.J. Iglesias, V. Almela, E. Primo-Millo, and M. Talón. 2002. The synthetic auxin 3,5,6-TPA stimulates carbohydrate accumulation and growth in citrus fruit. Plant Growth Regulat. 36:141-147.

Albrigo, L.G. and E.W. Stover. 2015. Effect of plant growth regulators and fungicides on Huanglongbing-related preharvest fruit drop of citrus. HortTechnology 25:785-790.

Alvarez, S., E. Rohrig, D. Solís, and M.H. Thomas. 2016. Citrus greening disease (Huanglongbing) in Florida: Economic impact, management and the potential for biological control. Agr. Res. 5:109-118.

Baldwin, E., A. Plotto, J. Bai, J. Manthey, W. Zhao, S. Raithore, and M. Irey. 2018. Effect of abscission zone formation on orange (Citrus sinensis) fruit/juice quality for trees affected by Huanglongbing (HLB). J. Agr. Food Chem. 66:2877-2890. 
Bleecker, A.B. and S.E. Patterson. 1997. Last exit: Senescence, abscission, and meristem arrest in Arabidopsis. Plant Cell 9:1169-1179.

Bové, J.M. 2006. Huanglongbing: A destructive, newly-emerging, century-old disease of citrus. J. Plant Pathol. 88:7-37.

Burns, J.K., C.R. Arias, I. Kostenyuk, M. Obraztsova, L. Pozo, Z. Wu, and G.Y. Zhong. 2000. Isolation, characterization and expression of abscission-related genes in citrus. Proc. Intl. Soc. Citrucult. IX Congr. p. 609-614.

Burns, J.K. and D.J. Lewandowski. 2000. Genetics and expression of pectinmethylesterase, endo-1,4- $\beta$-glucanase, and polygalacturonase in 'Valencia' orange. Acta Hort. 535:65-80.

Cataldi, T.R.I., G. Margiotta, L. Iasi, B. Di Chio, C. Xiloyannis, and S.A. Bufo. 2000. Determination of sugar compounds in olive plant extracts by anion-exchange chromatography with pulsed amperometric detection. Anal. Chem. 72:3902-3907.

Cheng, C., L. Zhang, X. Yang, and G. Zhong. 2015. Profiling gene expression in citrus fruit calyx abscission zone (AZ-C) treated with ethylene. Mol. Genet. Genomics 290:1991-2006.

Cho, H.-T. and D.J. Cosgrove. 2000. Altered expression of expansin modulates leaf growth and pedicel abscission in Arabidopsis thaliana. Proc. Natl. Acad. Sci. USA 97:9783-9788.

Cho, S.K., C.T. Larue, D. Chevalier, H. Wang, T.-L. Jinn, S. Zhang, and J.C. Walker. 2008. Regulation of floral organ abscission in Arabidopsis thaliana. Proc. Natl. Acad. Sci. USA 105:15629-15634. Chomczynski, P. and N. Sacchi. 1987. Single-step method of RNA isolation by acid guanidinium thiocyanate-phenol-chloroform extraction. Anal. Biochem. 162:156-159.

Easlon, H.M. and A.J. Bloom. 2014. Easy Leaf Area: Automated digital image analysis for rapid and accurate measurement of leaf area. Appl. Plant Sci. 2:1400033.

Etxeberria, E., P. Gonzalez, D. Achor, and G. Albrigo. 2009. Anatomical distribution of abnormally high levels of starch in HLB-affected Valencia orange trees. Physiol. Mol. Plant Pathol. 74:76-83.

Ferguson, L. and E.E. Grafton-Cardwell. 2014. Citrus production manual. Univ. California, Agr. Natural Resources, Oakland, CA.

Folimonova, S.Y., C.J. Robertson, S.M. Garnsey, S. Gowda, and W.O. Dawson. 2009. Examination of the responses of different genotypes of citrus to Huanglongbing (citrus greening) under different conditions. Phytopathology 99:1346-1354.

Goldschmidt, E.E. 1999. Carbohydrate supply as a critical factor for citrus fruit development and productivity. HortScience 34:1020 1024.

Goldschmidt, E.E., M. Huberman, and R. Goren. 1993. Probing the role of endogenous ethylene in the degreening of citrus fruit with ethylene antagonists. Plant Growth Regulat. 12:325-329.

Goldschmidt, E.E. and K. Koch. 1996. Citrus, p. 797-823. In: E. Zamski and A.A. Schaffer (eds.). Photoassimilate distribution in plants and crops. Marcel Dekker, New York, NY.

Goldschmidt, E.E. and S.P. Monselise. 1977. Physiological assumptions toward the development of a citrus fruiting model. Proc. Intl. Soc. Citrucult. 2:668-672.

Gómez-Cadenas, A., J. Mehouachi, F.R. Tadeo, E. Primo-Millo, and M. Talón. 2000. Hormonal regulation of fruitlet abscission induced by carbohydrate shortage in citrus. Planta 210:636-643.

González-Carranza, Z.H., K.A. Elliott, and J.A. Roberts. 2007. Expression of polygalacturonases and evidence to support their role during cell separation processes in Arabidopsis thaliana. J. Expt. Bot. 58:3719-3730.

González-Carranza, Z.H., C.A. Whitelaw, R. Swarup, and J.A. Roberts. 2002. Temporal and spatial expression of a polygalacturonase during leaf and flower abscission in oilseed rape and Arabidopsis. Plant Physiol. 128:534-543.

Goren, R. and M. Huberman. 1976. Effects of ethylene and 2,4-D on the activity of cellulase isoenzymes in abscission zones of the developing orange fruit. Physiol. Plant. 37:123-130.

Guo, H. and J.R. Ecker. 2004. The ethylene signaling pathway: New insights. Curr. Opin. Plant Biol. 7:40-49.
Halbert, S.E. 2005. The discovery of Huanglongbing in Florida. Proc. 2nd Intl. Citrus Canker Huanglongbing Res. Wkshp., Florida Citrus Mutual, Orlando, FL. p. H-3.

Halbert, S.E., C.L. Niblett, K.L. Manjunath, R.F. Lee, and L.G. Brown. 2000. Establishment of two new vectors of citrus pathogens in Florida. Proc. Intl. Soc. Citrucult. IX Congr. p. 1016-1017.

Hartmond, U., R. Yuan, J.K. Burns, A. Grant, and W.J. Kender. 2000. Citrus fruit abscission induced by methyl-jasmonate. J. Amer. Soc. Hort. Sci. 125:547-552.

Hellemans, J., G. Mortier, A. De Paepe, F. Speleman, and J. Vandesompele. 2007. qBase relative quantification framework and software for management and automated analysis of real-time quantitative PCR data. Genome Biol. 8:R19.

Iglesias, D.J., M. Cercós, J.M. Colmenero-Flores, M.A. Naranjo, G. Ríos, E. Carrera, O. Ruiz-Rivero, I. Lliso, R. Morillon, F.R. Tadeo, and M. Talón. 2007. Physiology of citrus fruiting. Braz. J. Plant Physiol. 19:333-362.

Jagoueix, S., J.-M. Bové, and M. Garnier. 1994. The phloem-limited bacterium of greening disease of citrus is a member of the $\alpha$ subdivision of the proteobacteria. Intl. J. Syst. Bacteriol. 44:379-386.

Jinn, T.-L., J.M. Stone, and J.C. Walker. 2000. HAESA, an Arabidopsis leucine-rich repeat receptor kinase, controls floral organ abscission. Genes Dev. 14:108-117.

Johnson, E.G., J. Wu, D.B. Bright, and J.H. Graham. 2014. Association of 'Candidatus Liberibacter asiaticus' root infection, but not phloem plugging with root loss on Huanglongbing-affected trees prior to appearance of foliar symptoms. Plant Pathol. 63:290-298.

Kender, W.J., U. Hartmond, J.K. Burns, R. Yuan, and L. Pozo. 2001. Methyl jasmonate and CMN-pyrazole applied alone and in combination can cause mature orange abscission. Scientia Hort. 88:107-120.

Kim, J. 2014. Four shades of detachment: Regulation of floral organ abscission. Plant Signal. Behav. 9:e976154.

Kim, J.-S., U.S. Sagaram, J.K. Burns, J.-L. Li, and N. Wang. 2008. Response of sweet orange (Citrus sinensis) to 'Candidatus Liberibacter asiaticus' infection: Microscopy and microarray analyses. Phytopathology 99:50-57.

Kimball, D. 1991. Citrus processing quality control and technology. Van Nostrand Reinhold, New York, NY.

Koch, K.E. and W.T. Avigne. 1984. Localized photosynthate deposition in citrus fruit segments relative to source-leaf position. Plant Cell Physiol. 25:859-866.

Li, C.Y., D. Weiss, and E.E. Goldschmidt. 2003a. Girdling affects carbohydrate-related gene expression in leaves, bark and roots of alternate-bearing citrus trees. Ann. Bot. 92:137-143.

Li, C.Y., D. Weiss, and E.E. Goldschmidt. 2003b. Effects of carbohydrate starvation on gene expression in citrus root. Planta 217:11-20.

Li, Y.C., J.X. Shi, D. Weiss, and E.E. Goldschmidt. 2003c. Sugars regulate sucrose transporter gene expression in citrus. Biochem. Biophys. Res. Commun. 306:402-407.

Liao, H.-L. and J.K. Burns. 2012. Gene expression in Citrus sinensis fruit tissues harvested from Huanglongbing-infected trees: Comparison with girdled fruit. J. Expt. Bot. 63:3307-3319.

Mafra, V., K.S. Kubo, M. Alves-Ferreira, M. Ribeiro-Alves, R.M. Stuart, L.P. Boava, C.M. Rodrigues, and M.A. Machado. 2012. Reference genes for accurate transcript normalization in citrus genotypes under different experimental conditions. PLoS One 7: e31263.

Mafra, V., P.K. Martins, C.S. Francisco, M. Ribeiro-Alves, J. FreitasAstúa, and M.A. Machado. 2013. Candidatus Liberibacter americanus induces significant reprogramming of the transcriptome of the susceptible citrus genotype. BMC Genomics 14:247.

Malladi, A. and J.K. Burns. 2008. CsPLD $\alpha 1$ and CsPLD 1 are differentially induced during leaf and fruit abscission and diurnally regulated in Citrus sinensis. J. Expt. Bot. 59:3729-3739.

Martinelli, F., S.L. Uratsu, U. Albrecht, R.L. Reagan, M.L. Phu, M. Britton, V. Buffalo, J. Fass, E. Leicht, W. Zhao, D. Lin, R. D’Souza, 
C.E. Davis, K.D. Bowman, and A.M. Dandekar. 2012. Transcriptome profiling of citrus fruit response to Huanglongbing disease. PLoS One 7:e38039.

Merelo, P., J. Agustí, V. Arbona, M.L. Costa, L.H. Estornell, A. Gómez-Cadenas, S. Coimbra, M.D. Gómez, M.A. Pérez-Amador, C. Domingo, M. Talón, and F.R. Tadeo. 2017. Cell wall remodeling in abscission zone cells during ethylene-promoted fruit abscission in citrus. Front. Plant Sci. 8:126.

National Center for Biotechnology Information (NCBI). 2018a. A tool for finding specific primers. 1 Nov. 2018. $<$ http://www.ncbi.nlm.nih. gov/tools/primer-blast/index.cgi?LINK_LOC=BlastHome $>$.

National Center for Biotechnology Information (NCBI). 2018b. RefSeq: NCBI reference sequence database. 1 Nov. 2018. $<$ https:// www.ncbi.nlm.nih.gov/refseq/>.

Nehela, Y., F. Hijaz, A.A. Elzaawely, H.M. El-Zahaby, and N. Killiny. 2018. Citrus phytohormonal response to Candidatus Liberibacter asiaticus and its vector Diaphorina citri. Physiol. Mol. Plant Pathol. 102:24-35.

Patharkar, O.R. and J.C. Walker. 2018. Advances in abscission signaling. J. Expt. Bot. 69:733-740.

Patterson, S.E. 2001. Cutting loose. Abscission and dehiscence in Arabidopsis. Plant Physiol. 126:494-500.

Patterson, S.E. and A.B. Bleecker. 2004. Ethylene-dependent and -independent processes associated with floral organ abscission in Arabidopsis. Plant Physiol. 134:194-203.

Pfaffl, M.W. 2001. A new mathematical model for relative quantification in real-time RT-PCR. Nucleic Acids Res. 29:e45.

Porat, R., B. Weiss, L. Cohen, A. Daus, R. Goren, and S. Droby. 1999. Effects of ethylene and 1-methylcyclopropene on the postharvest qualities of 'Shamouti' oranges. Postharvest Biol. Technol. 15:155-163.
Rio, D.C. 2015. Denaturation and electrophoresis of RNA with formaldehyde. Cold Spring Harb. Protoc. 2015:306-313.

Rosales, R. and J.K. Burns. 2011. Phytohormone changes and carbohydrate status in sweet orange fruit from Huanglongbinginfected trees. J. Plant Growth Regul. 30:312-321.

Ruiz, R., A. García-Luis, C. Monerri, and J.L. Guardiola. 2001. carbohydrate availability in relation to fruitlet abscission in citrus. Ann. Bot. 87:805-812.

Schneider, C.A., W.S. Rasband, and K.W. Eliceiri. 2012. NIH image to Image J: 25 Years of image analysis. Nat. Methods 9:671-675.

Slinski, S. 2016. Evaluation of HLB treatments. Citrus Ind. 2016 (Aug):10-12.

Spann, T.M. and W.C. Oswalt. 2008. Citrus greening effects on fruit size distribution and yield in citrus trees. Proc. Florida State Hort. Soc. 121:97-99.

Taylor, J.E., G.A. Tucker, Y. Lasslett, C.J.S. Smith, C.M. Arnold, C.F. Watson, W. Schuch, D. Grierson, and J.A. Roberts. 1991. Polygalacturonase expression during leaf abscission of normal and transgenic tomato plants. Planta 183:133-138.

U.S. Department of Agriculture. 2018. Florida citrus fruit size and drop 2017-18 report. U.S. Dept. Agr., Washington, DC.

Wang, X., D. Liu, A. Li, X. Sun, R. Zhang, L. Wu, Y. Liang, and L. Mao. 2013. Transcriptome analysis of tomato flower pedicel tissues reveals abscission zone-specific modulation of key meristem activity genes. PLoS One 8:e55238.

Yuan, R., Z. Wu, I.A. Kostenyuk, and J.K. Burns. 2005. G-proteincoupled $\alpha_{2 \mathrm{~A}}$-adrenoreceptor agonists differentially alter citrus leaf and fruit abscission by affecting expression of ACC synthase and ACC oxidase. J. Expt. Bot. 56:18671875. 
(A)

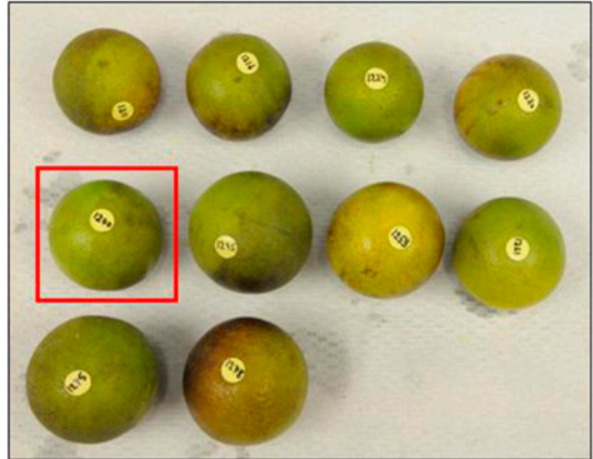

(B)

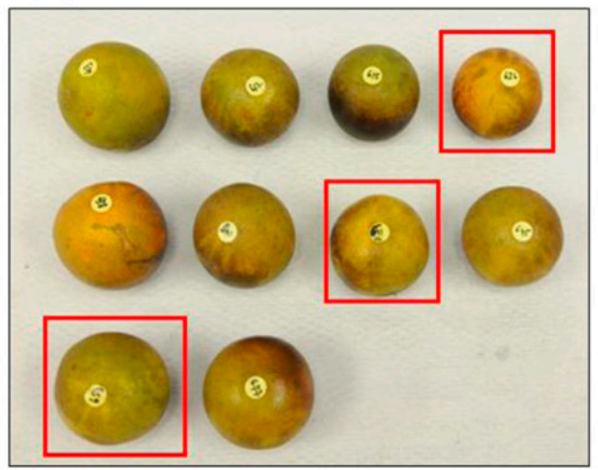

(C)

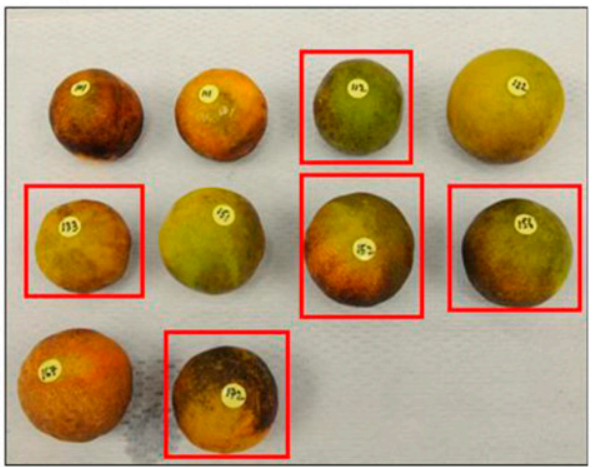

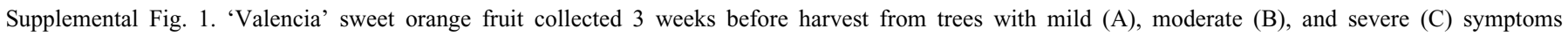
of Huanglongbing. Red squares indicate loose fruit (fruit detachment force $\leq 6 \mathrm{kgf}$ ). 